\title{
BEARING CAPACITY INVESTIGATION OF SILTY SANDY SOIL LAYER USING KUNZELSTAB TEST
}

\author{
C. Kererat \\ Rajamangala University of Technology Rattanakosin Wangklaikangwon Campus, Faculty of Engineering, \\ Department of Civil Engineering, Prachuap Khiri Khan, Thailand, email: chusak.k@rmutr.ac.th
}

Received: 09.03.2016 / Accepted: 12.04.2016 / Revised: 19.05.2016 / Available online: 31.05.2016

DOI: 10.1515/jaes-2016-0006

KEY WORDS: bearing capacity, silty sandy soil, Kunzelstab test, apex angle of cone, ground water level

\begin{abstract}
:
This study presents the effect of the 3 apex angles of cone and water levels on the bearing capacity of silty sandy soil (SM) layer by interpreting results from Kunzelstab test. The SM soil layer was prepared in the testing tank and it was used as the representative of sandy soil for some area in Thailand. As the results, the cone angle increase, a number of blows increase and the adjusted factors of the blows from the apex angles of $60^{\circ}$ and $180^{\circ}$ to be that of the apex angle of $90^{\circ}$ (control) were 1.118 and 0.878 , respectively. The obtained correlation between the blows and the internal friction angles of SM soil can be used for calculating the soil bearing capacity which lowers the ground surface of $0.6 \mathrm{~m}$. The soil bearing capacity of SM soil below ground water level decreases 70 to 75 percent (average values from testing results) comparing to that of dry soil. Moreover, the bearing capacity of SM soil above the water level up to $0.6 \mathrm{~m}$ decreases 25 to 30 percent (average values from testing results) comparing to that of dry soil at the same depth. Silty sandy soil layer was found determined to have lower bearing capacity due to higher ground water level. Therefore, the calculation of the soil bearing capacity in silty sandy soil layer should be considered the effect of ground water level.
\end{abstract}

\section{INTRODUCTION}

Foundation is a significant structure of building that foundation design must be known a bearing capacity of soil. Generally, the bearing capacity of soil can be interpreted from the results of soil investigation (Peck et al., 1974; Nanakerungsan, 1999). For the small buildings or the residences which lay on stiff soil, soil investigation maybe not has to perform but it can use in-situ test by using light weight penetration test namely Kunzelstab penetration test. This test can perform rapidly, economical expense and easy transportation (Kuvigidgraru, 1999; Krasaeteep and Thongchart, 2012; Sirisriphet and Santichaianant, 2015). Previous studies using Kunzelstab penetration test were developed by several researchers (e.g. GERD, 2000; Kaewwiset et al., 2010; Chanjeawchai, 2012; Ornura, 2012).

According to the standard of Kunzelstab penetration test (DIN 4049), an apex angle of cone is 90 degree but presently, the apex angle of cone used in this test is 60 degree which is not corresponding to the standard. Therefore, this research focuses the effect of the apex angle of 3 cones and the water levels on the bearing capacity of sandy soil layer. Moreover, the results can be used to correlate the internal friction angle of silty sandy soil and determine the bearing capacity by Terzaghi's equation (Terzaghi and Peck, 1967; Sakmanee and Chantawarangul, 2003; Sakmanee and Chantawarangul, 2006).

\section{MATERIALS AND METHODS}

\subsection{Experimental Materials and Apparatus}

Material used in this research is sandy soil as represent soil sample in area of Prachuap Khirikhan province. The results of a dry-sieving test show the passing No.200 sieve is $44.39 \%$ and grain size distribution curve of sandy soil is as shown in Figure 1. The physical properties are as follows: liquid limit (LL) of $18.15 \%$, plastic limit (PL) of $14.44 \%$, plasticity index (PI) of $3.17 \%$ and specific gravity of 2.68 . Soil type of soil which classify by Unified Soil Classification System (USCS) is silty sandy soil (SM).

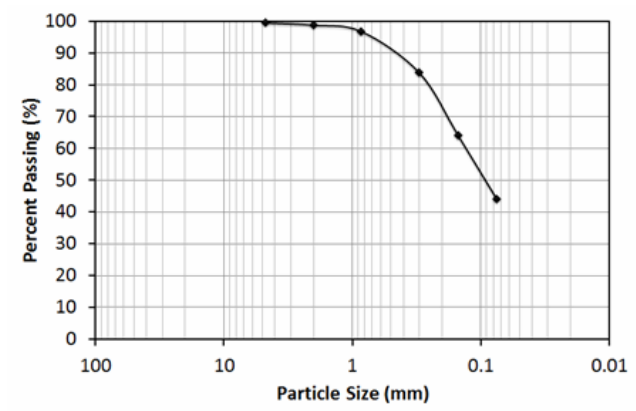

Figure 1. Grained size distribution curve of SM soil

The Kunzelstab penetrometer is as shown in Figure 2 which consists of (1) guild rod (2) sounding rod (3) hammer (4) anvil 
(5) base plate (6) penetration control and (7) the cone with the apex angles of $60^{\circ}, 90^{\circ}$ and $180^{\circ}$

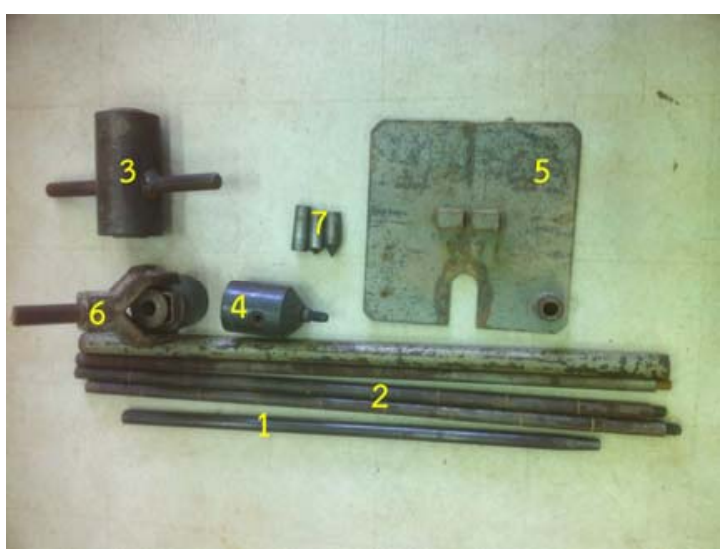

Figure 2. Kunzelstab penetrometer

\subsection{Soil Preparation in Testing Tank}

The steps of soil preparation can be described as follows:

1) Dry the soil sample by exposing to the sun as shown in Figure 3.

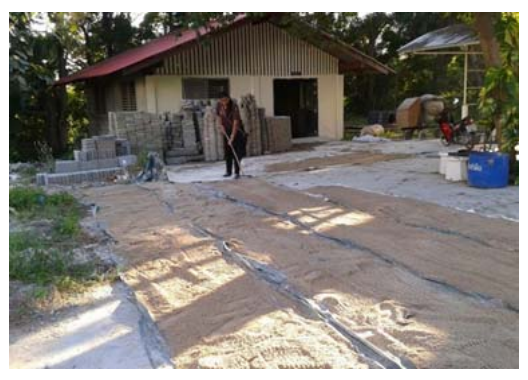

Figure 3. Exposition of soil sample

2) Dry silty sand was placed in the testing tank which is $1.0 \mathrm{~m}$ wide, $1.0 \mathrm{~m}$ long, and $1.8 \mathrm{~m}$ high. It was pluviated lift by lift as sand raining. Each lift thickness is $0.05 \mathrm{~m}$ and the dry density of $1.9 \mathrm{t} / \mathrm{m}^{3}$ is controlled every lift thickness until the soil layer full in the testing tank as shown in Figure 4.

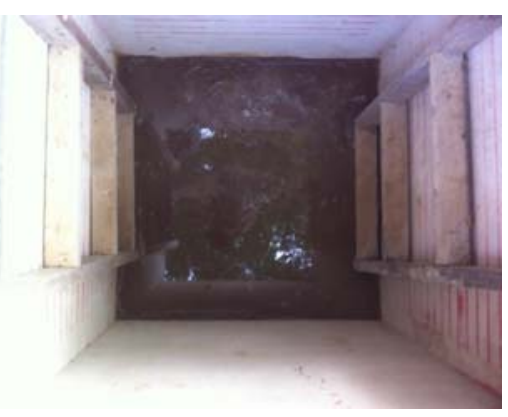

Figure 4. Soil preparation in testing tank

3) For the case of water level simulation, water was gradually added to the soil layer from bottom until reach the desired level which shown in Table 1.

\begin{tabular}{|c|c|c|c|}
\hline \multirow{2}{*}{$\begin{array}{c}\text { Apex } \\
\text { angle of } \\
\text { cone } \\
\text { (degree) }\end{array}$} & \multicolumn{3}{|c|}{$\begin{array}{c}\text { Water level from Bottom } \\
\text { (m) }\end{array}$} \\
\cline { 2 - 4 } & - & 1.0 & 1.5 \\
\hline 60 & SM-d-60 & SM-1.0-60 & SM-1.5-60 \\
90 & SM-d-90 & SM-1.0-90 & SM-1.5-90 \\
180 & SM-d-180 & SM-1.0-180 & SM-1.5-180 \\
\hline
\end{tabular}

Table 1. Abbreviation of the test condition

\subsection{Procedure of Kunzelstab Penetration Test}

Test procedure (Kuvigidgraru, 2001; Kererat, 2012) can be described as follows:

1) Place the base plate at the center of testing tank area. Assemble the cone to the sounding rod and connect to the base plate. Assemble the anvil, hammer and guide rod to the sounding rod as shown in Figure 5.

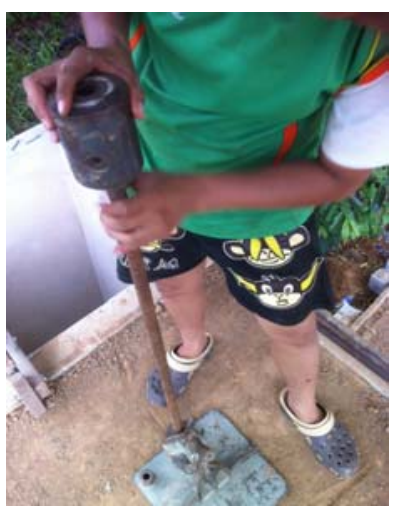

Figure 5. Instrument preparation

2) Testing was performed by using a $10 \mathrm{~kg}$ steel mass that falls $50 \mathrm{~cm}$ to drive $25 \mathrm{~mm}$ diameter cone into the soil layer as shown in Figure 6. The number of blows was recorded every a penetration depth of $20 \mathrm{~cm}$ of cone until the total depth of 1.6 $\mathrm{m}$. After that, the sounding rod was removed from the soil layer. Moreover, the test was performed under condition of water level simulation at $1.0 \mathrm{~m}$ and $1.5 \mathrm{~m}$ from the soil surface including the 3 apex angles of cone which are 60 degree, 90 degree and 180 degree, were changed for each test condition.

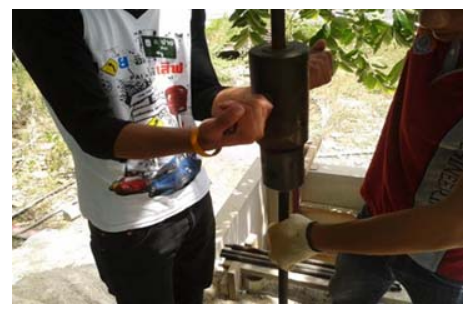

Figure 6. Kunzelstab penetration test

3) After finish testing, the soil samples were sampling by using the sampler which is the steel tube of $30 \mathrm{~mm}$ x $30 \mathrm{~mm}$ x 200 $\mathrm{mm}$. The depths of sampling are $0.2 \mathrm{~m}, 0.6 \mathrm{~m}, 1.0 \mathrm{~m}$ and $1.4 \mathrm{~m}$ from soil surface as shown in Figure 7 . These samples were 
西

DE GRUYTER

used to determine wet density and water content for soil preparation in direct shear test.

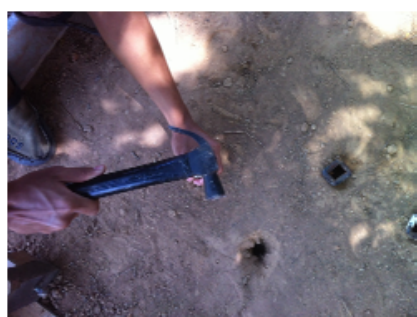

Figure 7. Soil sampling

4) Draw the graphs which show number of blows throughout the depth of testing to compare the condition of different the apex angles of cone including the effect of water level.

\subsection{Procedure of Direct Shear Test}

This test aims to determine the shear strength parameters of soil. The procedures of testing are as follows:

1) Prepare the soil sample that are the same density and water content at the sampling depth of $0.2 \mathrm{~m}, 0.6 \mathrm{~m}, 1.0 \mathrm{~m}$ and $\quad 1.4$ $\mathrm{m}$, respectively.

2) Prepare the desired loads of $3.8 \mathrm{~kg}, 11.5 \mathrm{~kg}$ and $19.1 \mathrm{~kg}$ which correspond to the overburden pressure at every sampling depth. Three tests that the applied loads of 0.5, 1 and 2 time desired load are performed for each desired load.

3) Perform testing until reach all cases of Kuzelstab penetration test.

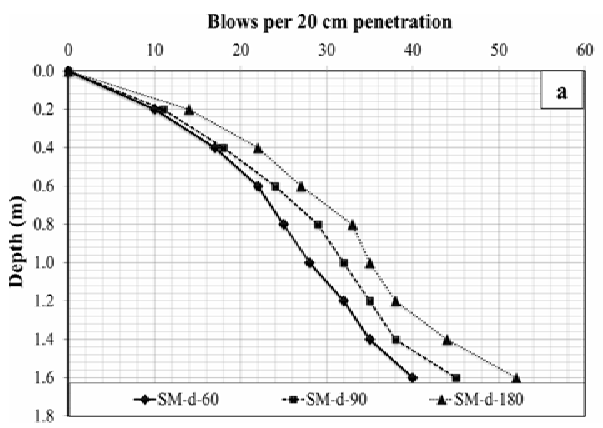

4) Draw the graphs which show the correlation of shear strength parameters and number of blows throughout the depth of testing.

\section{RESULTS AND DISCUSSION}

\subsection{Results from Kunzelstab Test}

According to the effects of the apex angles of cone and water levels, they can describe as follows:

1) Effect of the apex angles of cone on the blows of testing can be shown in Figure 8. They illustrate the comparison of blows for each cone at the same depth of testing. They reveal that if smaller apex angle, the cone resistance smaller. Therefore, the blows for the use of the 60 degree apex angle are smaller than that for the use of 90 degree apex angle at the same condition of soil preparation.

2) Effect of water level on the blows of testing can be shown in Figure 9. They illustrate the comparison of the blows for case of different water level at the same depth and the same apex angle. According to Figure 9(a), the blows increase along to the depth for dry soil condition because the overburden pressure increase. Figures 9(b) and 9(c) show that the blows near water level and below water level will decrease because the soil can be absorbed the water and then the water content will be increase. The blows at the same depth compare to dry soil condition found that the blows decrease about $70 \%$ to $75 \%$. Therefore, the water level affects the soil bearing capacity that it will be decrease when it reach $0.6 \mathrm{~m}$ above water level.

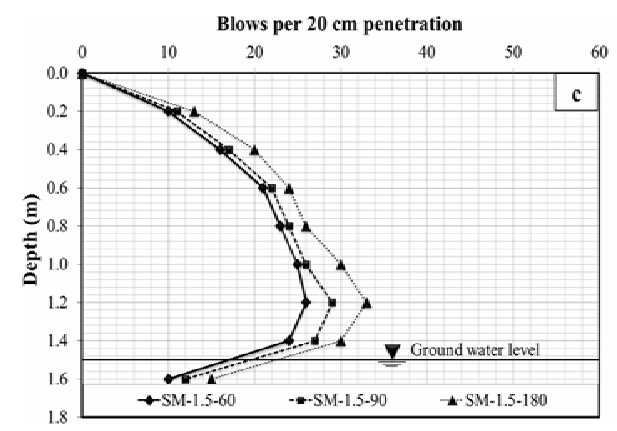

Figure 8. The comparison between the blows and the depth of testing for different apex angles (a) dry soil condition (b) soil with $1 \mathrm{~m}$ water level condition (c) soil with $1.5 \mathrm{~m}$ water level condition 

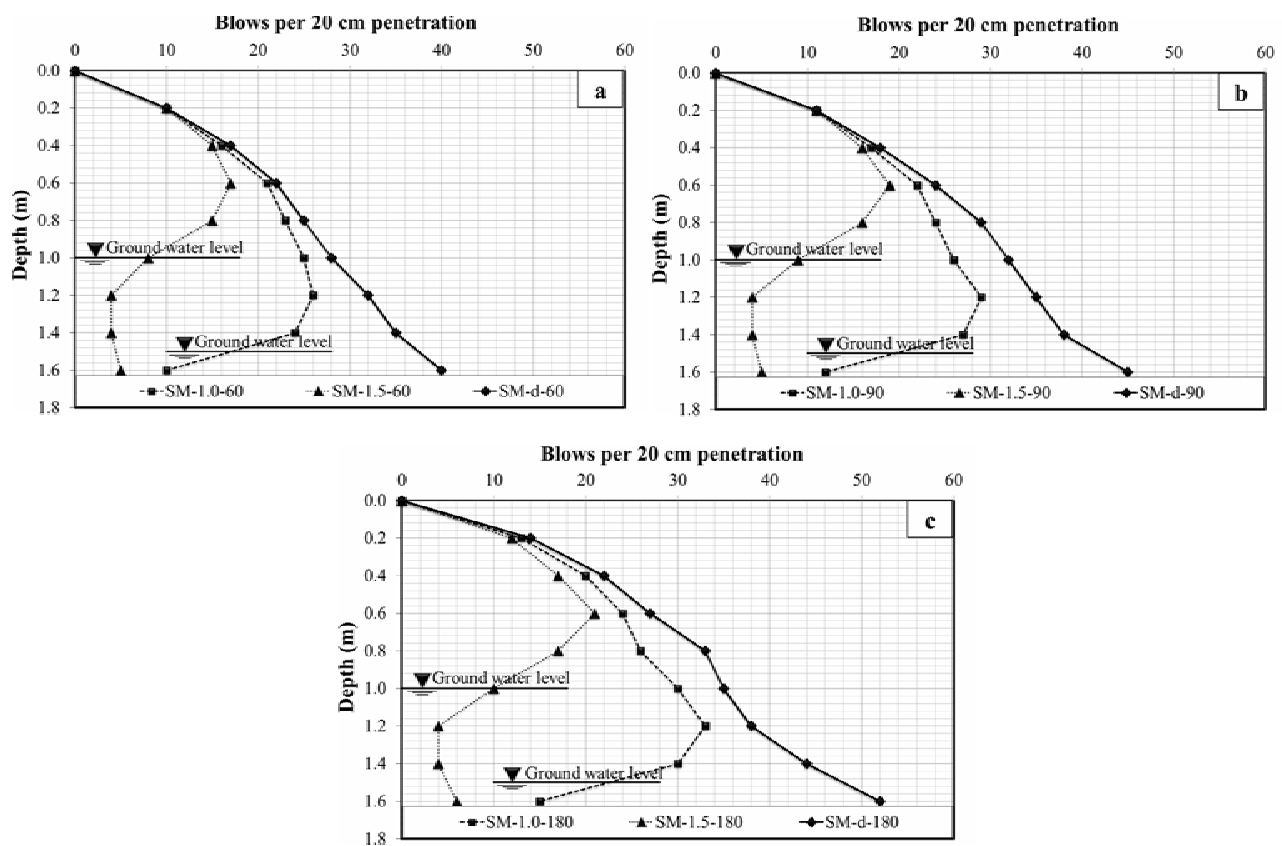

Figure 9. The comparison between the blows and the depth of testing for different water level (a) the apex angle of 60 degree (b) the apex angle of 90 degree (c) the apex angle of 180 degree

\subsection{Results from Direct Shear Test}

The description of testing results is shown in Tables 2 to 4 . According to Table 2, it reveals that shear strength parameters increase with depth. The blows of 11 to 38 (apex angle of 90 degree) and the internal friction angles of soil are about 35 to 40 degree show that the soil is the medium dense state which correspond to the data by Meyerhof (1956). For the case of water level (Table 3), the internal friction angle of saturated soil more decrease which is 7 to 9 degree when compare to the case of dry soil because of the effect of water content. Moreover, the data from Table 4 are also shown that the internal friction angle of saturated soil tend to decrease when it close to or below the water level. As the results, the translation from the blows to be the internal friction angle should be considered the blows below the surface of $0.6 \mathrm{~m}$ because the soil near the surface will move laterally.

\begin{tabular}{|c|c|c|c|c|c|c|c|c|}
\hline \multirow[b]{2}{*}{ Condition } & \multirow{2}{*}{$\begin{array}{l}\text { Depth } \\
\text { (m) }\end{array}$} & \multirow{2}{*}{$\begin{array}{c}\text { Moisture } \\
\text { content } \\
\text { (\%) }\end{array}$} & \multirow{2}{*}{$\begin{array}{l}\text { Density } \\
\left(\mathrm{t} / \mathrm{m}^{3}\right)\end{array}$} & \multicolumn{2}{|c|}{ Shear strength parameters } & \multicolumn{3}{|c|}{$\mathrm{N}_{\mathrm{KPT}}$} \\
\hline & & & & $\begin{array}{l}\text { Cohesion } \\
\left(\mathrm{kg} / \mathrm{cm}^{2}\right)\end{array}$ & $\begin{array}{l}\text { Internal } \\
\text { friction } \\
\text { angle }\end{array}$ & $\begin{array}{c}\text { Apex } \\
\text { angle } \\
60^{\circ}\end{array}$ & $\begin{array}{c}\text { Apex } \\
\text { angle } \\
90^{\circ}\end{array}$ & $\begin{array}{l}\text { Apex } \\
\text { angle } \\
180^{\circ}\end{array}$ \\
\hline \multirow{4}{*}{ SM-d } & 0.2 & 0 & 1.91 & 0.145 & 36.97 & 10 & 11 & 14 \\
\hline & 0.6 & 0 & 1.94 & 0.145 & 37.13 & 22 & 24 & 27 \\
\hline & 1.0 & 0 & 1.95 & 0.245 & 38.88 & 28 & 32 & 35 \\
\hline & 1.4 & 0 & 1.96 & 0.209 & 39.73 & 35 & 38 & 44 \\
\hline
\end{tabular}

Table 2. Engineering properties for the condition of dry soil

\begin{tabular}{|c|c|c|c|c|c|c|c|c|}
\hline \multirow[b]{2}{*}{ Condition } & \multirow{2}{*}{$\begin{array}{l}\text { Depth } \\
\text { (m) }\end{array}$} & \multirow{2}{*}{$\begin{array}{c}\text { Moisture } \\
\text { content } \\
(\%)\end{array}$} & \multirow{2}{*}{$\begin{array}{c}\text { Density } \\
\left(\mathrm{t} / \mathrm{m}^{3}\right)\end{array}$} & \multicolumn{2}{|c|}{ Shear strength parameters } & \multicolumn{3}{|c|}{$\mathrm{N}_{\mathrm{KPT}}$} \\
\hline & & & & $\begin{array}{c}\text { Cohesion } \\
\left(\mathrm{kg} / \mathrm{cm}^{2}\right)\end{array}$ & $\begin{array}{l}\text { Internal } \\
\text { friction } \\
\text { angle }\end{array}$ & $\begin{array}{c}\text { Apex } \\
\text { angle } \\
60^{\circ}\end{array}$ & $\begin{array}{c}\text { Apex } \\
\text { angle } \\
90^{\circ}\end{array}$ & $\begin{array}{l}\text { Apex } \\
\text { angle } \\
180^{\circ}\end{array}$ \\
\hline \multirow{4}{*}{ SM-1.0 } & 0.2 & 0 & 1.91 & 0.145 & 36.97 & 10 & 11 & 12 \\
\hline & 0.6 & 0 & 1.93 & 0.145 & 37.13 & 17 & 19 & 21 \\
\hline & 1.0 & 8.12 & 1.97 & 0.035 & 7.72 & 8 & 9 & 10 \\
\hline & 1.4 & 16.28 & 2.06 & 0.031 & 8.98 & 4 & 4 & 4 \\
\hline
\end{tabular}

Table 3. Engineering properties for the condition of soil with water level of $1.0 \mathrm{~m}$ 


\begin{tabular}{|c|c|c|c|c|c|c|c|c|}
\hline \multirow[b]{2}{*}{ Condition } & \multirow{2}{*}{$\begin{array}{l}\text { Depth } \\
\text { (m) }\end{array}$} & \multirow{2}{*}{$\begin{array}{c}\text { Moisture } \\
\text { content } \\
\text { (\%) }\end{array}$} & \multirow{2}{*}{$\begin{array}{l}\text { Density } \\
\left(\mathrm{t} / \mathrm{m}^{3}\right)\end{array}$} & \multicolumn{2}{|c|}{ Shear strength parameters } & \multicolumn{3}{|c|}{$\mathrm{N}_{\mathrm{KPT}}$} \\
\hline & & & & $\begin{array}{l}\text { Cohesion } \\
\left(\mathrm{kg} / \mathrm{cm}^{2}\right)\end{array}$ & $\begin{array}{l}\text { Internal } \\
\text { friction } \\
\text { angle }\end{array}$ & $\begin{array}{c}\text { Apex } \\
\text { angle } \\
60^{\circ}\end{array}$ & $\begin{array}{c}\text { Apex } \\
\text { angle } \\
90^{\circ}\end{array}$ & $\begin{array}{l}\text { Apex } \\
\text { angle } \\
180^{\circ}\end{array}$ \\
\hline \multirow{4}{*}{ SM-1.5 } & 0.2 & 0 & 1.91 & 0.145 & 36.97 & 10 & 11 & 13 \\
\hline & 0.6 & 0 & 1.93 & 0.145 & 37.13 & 21 & 22 & 24 \\
\hline & 1.0 & 0 & 1.95 & 0.245 & 38.88 & 25 & 26 & 30 \\
\hline & 1.4 & 14.29 & 2.08 & 0.036 & 7.40 & 24 & 27 & 30 \\
\hline
\end{tabular}

Table 4. Engineering properties for the condition of soil with water level of $1.5 \mathrm{~m}$

\section{CONCLUSIONS}

According to all data from testing, they can be used to develop the correlation between the blows and the shear strength parameters for the apex angles of 60, 90 and 180 degree, respectively. The translation from the blows to be the internal friction angle should be considered the blows below the ground surface of $0.6 \mathrm{~m}$. The correlation equation for translating the blows from the cone of 60 degree to the cone of 90 degree which is $\mathrm{N}_{90}=1.188 \mathrm{~N}_{60}$ and the correlation equation for translation the blows from the cone of 180 degree to the cone of 90 degree which is $N_{90}=0.878 \mathrm{~N}_{180}$ (the cone of 90 degree is the standard for Kunzelstab test according to DIN 4094-3). The bearing capacity of silty sandy soil layer which is above the water level of $0.6 \mathrm{~m}$ high until below the water level will be more decrease than that of the dry condition about 70 to $75 \%$. The internal friction angles for condition of saturated silty sandy soil are about 7 to 9 degree. For condition of dry silty sandy soil, the correlation equation between the internal friction angle of silty sandy soil and the blows is $\mathrm{y}=0.005 \mathrm{x} 2-0.1553 \mathrm{x}+$ 37.978 (where $\mathrm{y}=$ internal friction angle and $\mathrm{x}=$ blows). The recommendation for shallow foundation design should be consider the effect of the water level in case of the depth of foundation located above the water level of $0.6 \mathrm{~m}$.

\section{ACKNOWLEDGEMENTS}

I would like to thank Rajamangala University of Technology Rattanakosin, Thailand for providing funding for this research. Also, I thank Mr. Buncha Oncham, Mr.Somphop Mekkayai and Mr.Suttisak Intarasanit for operating Kunzelstab test.

\section{REFERENCES}

Peck, R.B., Hanson, W.E. and Thornburn, T.H., 1974, Foundation Engineering. Wiley, NewYork.

Nanakerungsan, B., 1999. Foundation Engineering and Tunnelling. Changmai University,Thailand

Kuvigidgraru, S., 1999. Soil Laboratory Testing. Library Nine Publishing, Bangkok, Thailand.

Krasaeteep, A. and Thongchart, S., 2012. "A Comparison of Cone Tip in Kunzelstab Penetration Test (KPT)" In: $17^{\text {th }}$
National Convention on Civil Engineering, Udonthani, Thailand.

Sirisriphet, Y. and Santichaianant, K., 2015. “An Automatic Kunzelstab Penetration Test” In: $5^{\text {th }}$ GEOINDO 2015 International Conference, Khon Kaen, Thailand.

Geotechnical Engineering Research and Development (GERD), 2000, The Report Strength of Soil Layer in Footing Area. Kasetsart University, Bangkok, Thailand.

Kaewwiset, N., Wiphathin, W. and Sootkhan, K., 2010. “The Correlation Between Engineering Properties of KKU soil and Results of Kunzelstab Penetration Test”, B.Eng. Project, Khon Kaen University, Khon Kaen, Thailand.

Chanjeawchai, P., 2012. "Relationship between Kunzelstab number and unconfined compressive strength for stiff Chiang Mai clay”, B.Eng. Project, Chiang Mai University, Chiang Mai, Thailand.

Ornura, T., 2012. "Relationship Between Kunzelstab Number and SPT Number for Stiff Chiang Mai Clay”, B.Eng. Project, Chiang Mai University, Chiang Mai, Thailand.

Terzaghi, K. and Peck, R.B., 1967. Soil Mechanics in Engineering Practice. Wiley, NewYork.

Sakmanee, A. and Chantawarangul, K., 2003. "Soil exploration by dynamic light penetrometer" In: the 41th Kasetsart University Annual Conference, Bangkok, Thailand, pp. 490-497.

Sakmanee, A. and Chantawarangul, K., 2006. "Dynamic penetrometer resistance in sand" in: the 11th National Convention on Civil Engineering, Phuket, Thailand.

Kuvigidgraru, S., 2001. Soil Investigation: Boring, Sampling and Field Test. Kasetsart University Press, Bangkok, Thailand.

Kererat, C., 2012. "Manual of soil mechanics laboratory" Rajamangala University of Technology Rattanakosin, Prachuap Khirikhan.

Meyerhof, G.G., 1956. Penetration tests and bearing capacity of cohesionless soils. Journal of the Soil Mechanics and Foundations Division, 82 (1), pp. 1-19. 